\title{
Galvanic Tripartite Amazon River Basin Macro- Imagineering
}

\author{
Richard Brook Cathcart \\ GEOGRAPHOS, Burbank, California, USA.
}

Received:_16 August 2018

/ Accepted:__02 September 2018

/ Published: _ 20 October 2018

\begin{abstract}
Referencing basic statements on macro-engineering's innovation-phase organization penned separately by Panero and Davidson, Team Geographos offers a new global commerce enhancing tripartite transportation macro-project, the postulated Trans-Pacific Brazil-Peru-China Trade Route. The latitudinal TPB-P-CTR may become an economically feasible substitute or supplement to a 21 st Century China-supported trans-American railway designed to connect Peru's Pacific Ocean coast with Brazil's Atlantic Ocean coast. In effect, a New World-originated concept that could globalize the developed infrastructure of the entire Amazon River Basin. Whilst certainly remarkably speculative, technically, the suggested TPB-P-CTR could create common destinies (yet still multi-national) for tropic zone of Peru and Brazil, operationalized by substantial financial and technical inputs mainly from China's temperate zone seaport-based communities.
\end{abstract}

Key words: Global commerce, macro-engineering, tripartite transportation macro-project.

Resumo: Fazendo referência a declarações básicas sobre a organização da fase de inovação da macroengenharia, escritas separadamente por Panero e Davidson, a Team Geographos oferece um novo macroprojeto de transporte tripartido que fortalece o comércio global, a postulada Transpacífico Brasil-Peru-China. A latitudinal TPB-P-CTR pode se tornar um substituto ou suplemento economicamente viável para uma ferrovia transamericana com suporte da China do século 21, projetada para conectar a costa do Oceano Pacífico no Peru com a costa do Oceano Atlântico no Brasil; com efeito, um conceito originado no Novo Mundo que poderia globalizar a infraestrutura de toda a bacia do rio Amazonas. Ainda que em grande medida especulativo, do ponto de vista técnico o CTR-TPB sugerido poderia criar destinos comuns, mas ainda multinacionais, para a região do Peru e do Brasil, operacionalizados por substanciais insumos financeiros e técnicos, principalmente das comunidades baseadas em portos da zona temperada da China.

Palavras-chave: Comércio global, macroengenharia, macroprojeto de transporte tripartite.

\section{Introduction}

The cover-art of the 26 May 2011 issue of the UK's weekly periodical The Economist illustrated a

Corresponding Author: Richard Brook Cathcart, GEOGRAPHOS, rbcathcart@gmail.com. supposed machine-fabricated planet Earth metallic skeleton and bolted exterior anthropocentric bioshell are shown as beginning to dislodge under the incessant impact of industrialized Homo sapiens actions during the commonly uncelebrated "Anthropocene" [1]. A techno-centric philosophy of Earth-bioshell management does not deny that alternatives are options, also it posits that humans ought to do without 
some unmentionable macro-projects; an outdoor glass-tubed escalator recently bruited to accommodate unfit and elderly tourists to effortlessly and quickly achieve the breathless heights of Machu Picchu is, perhaps, an exemplar bizarre macro-project! Team Geographos refrains from indulgence in zany mind-fancies but, instead, rigorously seeks to hone professional Macro-Imagineering as a design methodology to reform and reframe complex geo-physiological/geo-political situations reflectively so as to jump-start collective creativity in a desired landscape developmental direction; "scalability" is the key function of any particular world regional system intended by its human molders to cause a vast landscape transformation - that is, to reshape an entire landscape into a new operative system anthropogenically [2]. For example, future trans-Arctic Ocean shipping, using the shortest hypothesized crossing from the North Atlantic Ocean through the strategic Bering Strait into the North Pacific Ocean permits circumvention of territorial waters and Exclusive Economic Zones of adjacent ecosystem-nations [3]. And, like Earth's Southern Hemisphere Polar Zone, the Northern Hemisphere's Polar Zone will probably become then, as a nearly contemporary regulatory supply-management regime, policed by un-crewed aerial vehicles used in air-fleets owned by competing or complementary ecosystem-country robot flock administers [4]. "The Beijing-proposed trans-American railway between the Atlantic and Pacific resembles the Pacific Railroad constructed between 1863 and1869 in the U.S., the difference being that the planned new 'silk' transcontinental railway will cut across the Andes and link port cities on the Pacific and Atlantic coasts of Peru and Brazil" [5]. Such an over-arching proposed mid-21st Century infrastructure assets management scheme could also be applied efficiently to the developing Amazon River Basin. In other words, the Trans-Pacific Brazil-Peru-China Trade Route (TPB-P-CTR) can be transformative, rapidly, intentionally and profoundly resulting from the fair and equitable purchasing applications of money and sophisticated geographically large-scale technologies, done mostly without enforced migration of any human inhabitants of the directly-affected Amazon River Basin and deeply accidented Andes Mountains landscapes within Brazil and Peru [6]. Interestingly, some of the Amazon River Basin's populace may, or may not, already share ancient genetic kinship with modern-day Polynesia's extant population [7]! Brazil is homeland to the world's greatest number of Japanese immigrants.

\section{Macro-Imagineering phenomenology}

21st Century ecosystem-country infrastructure developmental macro-problems can seem to be intellectually intractable. In part, it is because of diminishment of their news-worthy prevalence that leads many persons to perceive more macro-problems impending their daily lives [8-10]. Most macro-projects are one-of-a-kind temporary endeavors where traditional management principles are inapplicable or unsuitable and where funders reserve the lawful right to cancel any purposeful macro-project for almost any reason since macro-projects require serial years of planning and final installation and because "Macro-engineering investments are preclusive; they imply basic choices among competing systems and values; once in place, they are apt to last a very long time", according to attorney macro-engineer Frank Paul Davidson (1918-2014) [11]. Therefore, Tropic Zone Macro-Imagineering is the study and outlining plan-preparation for the largest Macro-engineering public-works which educated and technologized groups of people can accomplish at any particular period of time in a specified, delimited and demarcated world-region.

Changes in the range of the Earth's two Hadley cells as well as the planet's Walker circulation is causing the Tropic Zone climate regime of the Amazon River 
Basin to increase in area, widening about 0.20 of latitude per decade [12]; these significant broadening climate regime range changes are indicated by record-breaking increased Basin flooding event-processes. The idea of the Tropic Zone rain-forest as a vegetation type was first neologized by Andreas Franz Wilhelm Schimper (1856-1901) in Planzengeographie auf physiologischer Grundlage (1898). However, unrecognized then, the Amazon River Basin's rain-forest was not pristine, untouched by Homo sapiens [13]; in fact, today's rain-forest may really be a tertiary vegetation type [14]! Ages ago, fixed settlements were not precluded from the vicinities of natural Amazon Basin rivers and lakes: for example, on the Belterra Plateau located south of the present-day city of Santarem, Brazil, capacious large natural and small anthropogenic landscape depressions were at once used grouped settlors as freshwater reservoirs. Today, the total drainable Amazon River Basin freshwater storage amounts to approximately 1,766 cubic kilometers, of which about $65 \%$ rests on the ground surface [15]. Some 3,680 kilometers from the Amazon River's mouths, Iquitos, Peru, situated at topographic elevation of 104 meters, is currently the world's farthest inland head of navigation for ocean-going vessels-essentially towed or self-propelled big barges - drawing a little more than 4 meters for safe navigation. The engineer-visionary Robert Panero (1928-2001) devised the early-1970s "Amazon Concept", a proposal to develop seven human-formed low-crested - 10-15 meters-high networked earthen dams that "...treats the [surface-flowing river freshwater] itself and [widespread homogeneous] flatness of the topography as the biggest assets of the area" [16].

A current consensus opinion Team Geographos' members hold is that Panero's river and lake interlinking "Amazon Concept" ought to be thoroughly re-examined because the relatively flat Brazilian Amazon Basin is unfavorable for high-generation mode hydropower facilities since such renewable energy production requires marked localized elevational gradient at all dam sites. Nevertheless, it would seem ecologically and economically prudent to materialize low-head run-of-river hydropower plants emplaced within systematized earthen embankments suggested by the "Amazon Concept", thus obviating more disruptive to natural river-flows reinforced-concrete dams emplaced in the Andes Mountains [17]. The Andes mountain range to the west forms about 13\% of the Amazon River Basin upstream of Obidos and current permanent infrastructure development plans have the goal of emplacing nearly 50 big dams within the watershed of the often meandering, shallow-less than 2 meters-Ucayali River, a major tributary of the Amazon River.

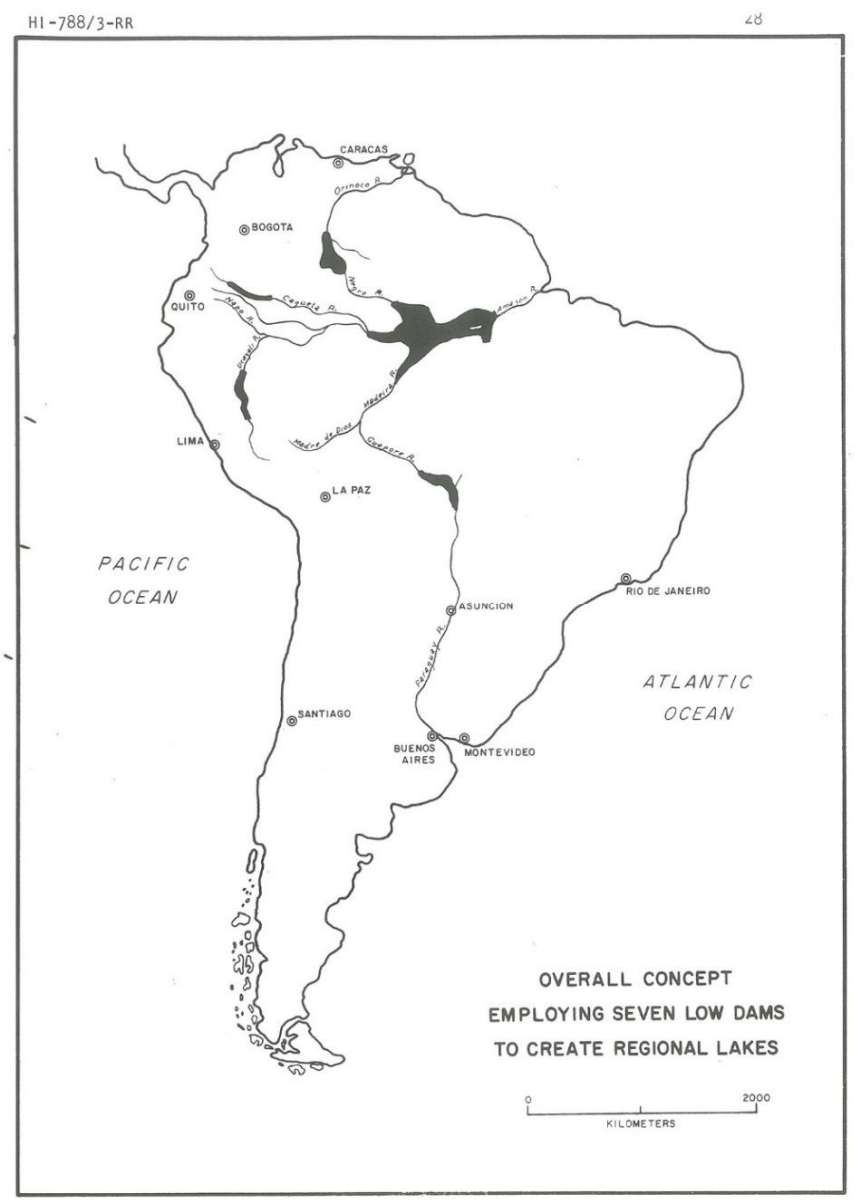

Figure 1. Robert Panero's astounding "Amazon Concept" including seven interconnected lakes formed 
by low-crested earthen dams that can be removed at will to induce the sluicing of accumulated reservoir sediment downstream. Concrete mega-dams sometimes require a decade to install and are indubitably vulnerable to currency volatility, inflation, corporate insolvencies, domestic political and international geopolitical tensions. Panero's smaller, more flexible hydropower macro-projects can be built of dredged earth and prefabricated powerhouses and put online quicker. Anthropogenic earthen barriers are more easily adapted to any subsequent Tropic Zone societal environmental concerns.

A fascinating plus feature for Robert Panero's earthen dams is that they are scalable and removable and, thus, can be utilized to ameliorate sedimentation of shallow lowland reservoirs. Worldwide, more than 82,891 small hydropower plants are reported operating or under construction [18]. Robert Panero's Macro-Imagineering inspiration adopted the fabled "Great Waterways Project of South America" which, if constructed, would bisect South America longitudinally [19]. Aspects of his comprehensive vision appear especially useful in our time due to notable climate regime change, whatever the origin and probable result: namely, the known seasonal inflammability of the Amazon River's floodplain vegetations are a severe existential vulnerability for the Amazon River Basin's remaining rain-forest vegetation [20] and annually pulsing river runoffs are, since 1982, known to be indisputably beneficial related to the complex tasks of lowland Tropic Zone wetland restorationists [21]! Increases in aerial carbon dioxide and higher temperatures can benefit Brazil's commercial soybean, maize and rice production [22]; a large area of South America encircling the unrealistically safeguarded, biodiverse central Amazon River Basin, has been adjudged by demographic experts to be a geographical alternative for future human settlement by, or before, AD 2030 [23] (Figure $1)$.

\section{Trans-Atlantic Ocean Brazil-Africa Trade Route}

Obviously latitudinal in prescribed geographical pattern, such a commercial trade route will bisect South America's Tropic Zone landscape; a latitudinal geographical orientation for virtually all industrial infrastructures dependent on the Amazon River's water is a Macro-Imagineering given. Team Geographos and others [24-25] have comprehensively proposed costly intercontinental freshwater pipelines to convey freshwater collected at a mouth of the Amazon River [26] for controlled transport to Africa. The outflow harvested for shipment overseas via pipeline is insufficient to cause any meridional dipole ocean surface temperature anomaly from developing in the equatorial North Atlantic Ocean [27]. Large-volume freshwater carriers generally referred to as Stauber Bags [28] can be used also and these have the practical and preferential advantage of mobility: for instance, such massive towed plastic water-barges may be used during the 21st Century to supply freshwater to Sao Paulo, Brazil and Cape Town, South Africa [29]! Both commercial fresh-water transport systems are innovative, environmentally sound ways of salvaging much-need freshwater, a valuable resource that would otherwise be lost by dilution in the world-ocean. And, each can perform a, perhaps, necessary future task as part of a vaster infrastructure to control the delta mouths of the Amazon River with less massive functional barriers fundamentally dissimilar to those expensively affixed already to The Netherlands' multiple continent river deltas. That is, the popularly postulated global sea-level rise during the 21 st Century surely means the Amazon River's salinity front, now about 150 kilometers seaward of its distributaries, may shift closer to mainland South America and, as well, the tidal part of the main-stem river may migrate upstream (pushed further inland) during seasonal low-flow periods than its present-day 1,000 kilometers [30]! To preclude such extensive destruction of the Amazon River Basin's extant vegetations, it seems 
prudent to install a large fabric parachute dam on the main stem of the river upstream of its mouths. Figure 2. A dam-regulated Amazon River could foster freshwater exports by closer proximity or connected adjacency to Brazil's technically isolated Amazon River delta.

\section{Trans-Pacific Ocean Brazil-Peru-China Trade Route (TPB-P-CTR)}

On 15 June 2018, esteemed and designated representatives of the national governments of Brazil, Peru, Bolivia and Paraguay met briefly in Lima, Peru to search for agreement on the realization of a 3,800 to 5,300 kilometer-long bi-oceanic railway that would permit unobstructed cross-continental freight transport. If materialized, the cost to connect Sao Paulo, Brazil and the seaport of Ilo in southern Peru might be as much as 2018 USD $\$ 60$ billion. The boldness of this envisioned railroad is evidenced today by the absence of continentalized international rail connections! Railways encouraging tourism are functional-for instance to move tourists close to Machu Picchu [32]. (Since most tourists suffer air-sickness above altitudes of 2,500 meters; China was obligated to air-pressurize its luxurious rolling stock of passenger wagons for its completed Tibet railway.) Referencing Tropic Zone Andes Mountains, non-aerial commercial traffic is almost entirely absent because highway, pipeline and railroads often require long tunnels and numerous bridges [33]. Between 1987 and 2010, the tri-national (Brazil-Peru-Bolivia) region situated in the southwestern Amazon Basin was the essential site for construction work on the Inter-Oceanic Highway [34-35].

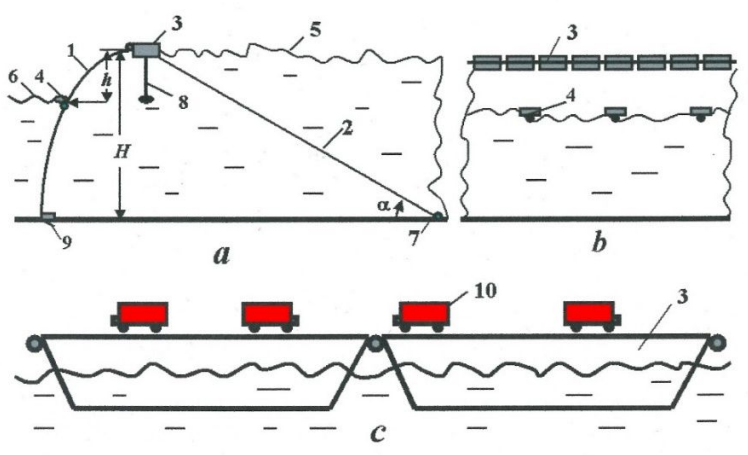

Figure 2. In this illustration $\# 5$ signifies the ponded freshwater of the Amazon River situated upstream of an anchored and bulging fabric dam signified by \#1. The fabric is impermeable. However, necessary freshwater-releases into the world-ocean, indicated by "6", must occur as required to maintain structural stability, with articulated barges shown here balanced by pendulum keels, \#8. Symbol \#3 represents serially well-linked pontoons serving as a transportation bridge, supporting many types of modern high-speed vehicles-trucks, automobiles, buses, standard trains, even superincumbent flexible Hyperloop tubes-to points of origination and destination north and south of the Amazon River but upstream of its distributaries to the Atlantic Ocean. Previously, a similar dam has been proposed to prevent the Mediterranean Sea from equalizing to the potential sea-level of a higher-than-present North Atlantic Ocean during the $21^{\text {st }}$ Century [31] (Figure courtesy Dr. Alexander A. Bolonkin).

Recently enlarged to efficiently pass the enormous bulk cargo and shipping container vessels of modern-day international shipping fleets, the Panama Canal has been supplemented with a profitable parallel route freight-carrying railway [36]! South America's first railroad, designed and built by the macro-engineer Ernest Adam Malinowski (1818-1899), first connected inland Lima and the coastal port of Callao in Peru by 1851. Modernization of this railway has been forecast by the Polytechnic University of Turin, Italy, civil 
engineers Bruno Dalla Chiara and Nicola Covielio in their 2018 report "Study of the layout and simulation of the operation of a single-track railway: the project of a transandino tunnel in Peru. A single-line railway: the design of a trans-Andean tunnel in Peru" ${ }^{1}$.

"The Concorde supersonic airplane operated scheduled services from 1976 until 2003 when it was honorably retired. The first corporation to order the Concorde, Panair do Brazil, reserved three of the prospective speedy aircraft from 24 July 1963 until March 1973; the Amazon River port of Manaus was intended to be one of its destinations" [37]. With the early-21st Century final development of hypersonic vehicles with aircraft-like access to outer space, the $+17,000$-kilometer expanse separating the seaport of Callao from Shanghai, China will be trivialized in terms of flight time! Even ocean-going container ships are slated for almost total robotization by major commercial operators before 2025. Surprisingly, Space Elevators [38] are proposed as yet an even cheaper means to exploit the voluminous extraterrestrial realm of outer space and which may have a base-station at Macapá, Brazil. But, let's get back to Earth! Since quite large ships can presently reach Manaus and smaller ships can reach Iquitos at 104 meters elevation and populated by $400,000+$ persons, it seems shallow-draft barges can navigate upstream on the Ucayali River almost 1,600 kilometers (Figure 3).

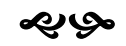

${ }^{1}$ Via the www, please GOTO: http://webthesis.biblio.polito.it/id/eprint/8251.

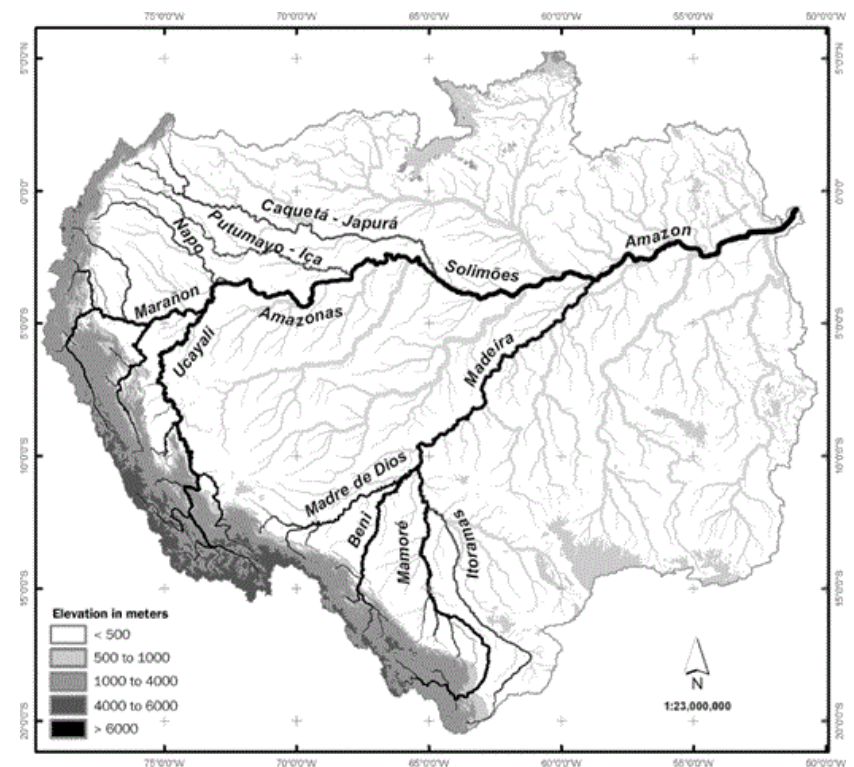

Figure 2. A view of the Amazon basin and its potential of navigability.

\section{Final Remarks}

The straight-line distance between Pucallpa, Peru, situated on a tributary of the Amazon River named Ucayali River, and Callao, the extant primary seaport of Peru facing the un-placid Pacific Ocean, is about 500 kilometers. How will it become possible and economical to move all 21st Century Brazilian exports destined for Asia to be shifted from the Amazon River Basin to the river-port of Pucallpa, Peru then transported overland by encapsulated-freight delivery Hyperloop? To be sure, some wily proponents of mediatized Macro-Imagineering are adept at playing to the egos of governmental and corporate decision-makers by promising breakthroughs during their popular public reign whilst downplaying the technical unknowns that must be surmounted. (Team Geographos eschews such persons!) Callao was completely demolished by tsunami in 1746 but it has adopted macro-engineering measures to forestall any future catastrophe of that scale. The barely navigable Ucayali River can be dredged but it could also be the watery route for an over-freshwater intermodal Hyperloop mimicking the 2015-completed highway 
that now links Xingshang County and the Zhaojun Bridge in Hubei Province, China. Whilst technical specifications for Hyperloop installations remain to be fully calculated and prototyped, most advisors allege the closed-guideway (tube) can have a greater than $0.1 \%$ grade - that is, steepness of approximately one meter per linear kilometer.

In the Portuguese language "macro-engineering" is "macroengenharia" and in the Spanish language it is "macroingenieria". So, Macro-Imagineering's professionals in Brazil and Peru ought not to have much difficulty in communicating their conceptions, plans and instigations! Genetic research and recorded history have established as fact that the Andes Mountains were breached centuries ago insofar as the movement of living humans and human-valued cargoes is concerned. For Team Geographos, the Amazon River Basin intimates its future 21st Century role in commerce as a "Wish Fulfilment Hub" with industrialization eventually converting the region into Asia's "Amazon.com" raw material and finished product resource worksite-warehouse!

\section{References}

[1] Lenton, T.M and Latour, B. 2018. "Gaia 2.0" Science 361: 1066-1068.

[2] Peloggia, A.U.G. 2018. "The Rock Cycle of the Anthropocene: Inserting Human Agency into the Earth System" Revista do Instituto Geologico, Sao Paulo 39: 1-13.

[3] Stephenson, S.R. et al. 2018. "Climatic Responses to Future Trans-Arctic Shipping” Geophysical Research Letters 45: 1-11.

[4] Mustafa, O. et al. 2018. "State of knowledge: Antarctic wildlife response to unmanned aerial systems" Polar Biology 41: 2387-2398.

[5] Nobis, Adam 2017 "The New Silk Road, Old Concepts of Globalization, and New Questions" Open Cultural Studies 1: 206.
[6] Santos-Granreo, F. 2002. "Boundaries are made to be crossed: The magic and politics of the long-lasting Amazon/Andes Divide" Indentities: Global Studies in Culture and Power 9: 545-569.

[6] Anderson, E.P. et al. 2018. "Fragmentation of Andes-to-Amazon connectivity by hydropower dams" Science Advances 4: eaao1642.

[7] Skoglund, P. et al. 2015. "Genetic evidence for two founding populations of the Americas" Nature 525: 104-108.

[8] Levari, D.E. et al. 2018. "Prevalence-induced concept change in human judgment" Science 360(6396): 1465-1467.

[9] Allan, J.A. 1983. "Natural resources as national fantasies" Geoforum 14: 243-247.

[10] Locatelli, G. et al. 2017. "Corruption in public projects and megaprojects: There is an elephant in the room!" International Journal of Project Management 35: 252-268.

[11] Davidson, F.P. 1983. "Macro-Engineering: An International Perspective" Space Solar Power Review 4: 66.

[12] Barichivich, J. et al. 2018. "Recent intensification of Amazon flooding extremes driven by strengthened Walker circulation" Science Advances 4: eaat8785.

[13] Lewis, C. et al. 2017. "Persistent effects of pre-Columbian plant domestication on Amazon forest composition" Science 355: 925-931.

[14] Tregidgo, D.J. et al. 2017. "Rainforest metropolis casts 1,000 km defaunation shadow" Proceedings of the National Academy of Sciences [USA] 114: 8655-8659.

[15] Tourian, M.J. et al. 2018. "The Total Drainable Water Storage of the Amazon River Basin: A First Estimate Using GRACE" Water Resources Research 54((5). https://doi.org/10.1029/2017WR021674.

[16] Panero, R. 19 July 1972. "The Amazon-A Catalytic Approach to Development" Hudson Institute-1664-RR. 26 pages.

[17] Forsberg, B.R. et al. 2017. "The potential impact of new Andean dams on Amazon fluvial ecosystems" PLOS ONE 12: e0182254. 
[18] Couto, T.B.A and Olden, J.D. 2018. "Global proliferation of small hydropower plants-science and policy". Frontiers in Ecology and the Environment. http://onlinelibrary.wiley.com/doi/10.1002/fee.1746/abst ract?campaign $=$ wolearlyview.

[19] Gioia, C.J. 1987. "The Great Waterways project of South America" Project Appraisal 2: 243-250.

[20] Flores, B.M. et al. 2017. "Floodplains as an Achilles' heel of Amazonian forest resilience" Proceedings of the National Academy of Sciences [USA] 114: 4442-4446.

[21] Junk, W.J. 1999. "The flood pulse concept of large rivers: Learning from the tropics" Archiv fur Hydrobiologie 115: 261-280.

[22] Mariani, L. 2017. "Carbon plants nutrition and global food security". The European Physical Journal Plus 132: 69.

[23] Forman, R.T.T. and Wu, J. 2016. "Where to put the next billion people". Nature 537: 608-611.

[24] Badescu, V., Isvoranu D. and Cathcart, R.B. 2009. "Transatlantic Freshwater Aqueduct". Water Resources Management 24L 1645-1675,

[25] Cedeno, B.O.B. April 2009. "Economic valuation of two technologies to import water. A case study of Morocco". UNESCO-IHE Institute for Water Education MSc Thesis WM.09.04.

[26] Ward, N.D. et al. 2018. "The Amazon River's Ecosystem: Where Land Meets the Sea". EOS Earth and Space Science News 99: 2933.

[27] Jahfer, S. et al. 2018. "Long-term impact of Amazon River runoff on northern hemisphere climate". Scientific Reports 7: 10989.

[28] Cathcart, R.B., Finkl, C.W. and Badescu, V. 2011. "Antarctica-to-Western Australia Liquid Freshwater Shipments Using Stauber Bags in a Paternoster-Like Transfer System: Inaugurating a Southern Ocean Antidrought Action Sea-Lane". Journal of Coastal Research 27: 1005-1018.

[29] Muller, M. 2018. "Lessons from Cape Town's drought”. Nature 559: 174-176.
[30] Hoitink, A.J.F. and Jay, D.A. 2016. "Tidal river dynamics: Implications for deltas". Reviews of Geophyics 54: 240-272.

[31] Cathcart, R.B., Macro-Imagineering our Dosmozoicum , Lambert Academic Press (2018) page 144.

[32] Allis, T. et al. 2016. "Railway for Tourism in South America: An approach on its Uses". Journal of Trafic and Transportation Engineering 4: 339-349.

[33] Borsdorf, A. and Stadel, C.. "The Andes Transport Space". Pages 259-284 IN The Andes: A Geographical Portrait. Springer International Publishing (2015). 